\title{
REPORT OF THE EXECUTIVE COMMITTEE 1952-54
}

\section{CoUntries AdHERING to THE UNion}

Since the last General Assembly of the I.A.U., Venezuela has adhered to the Union in I953 and Israel and the Lebanese Republic in I954.

The following is the list of countries adhering to the Union and of the adhering organizations:

\begin{tabular}{|c|c|c|c|c|}
\hline \multicolumn{3}{|c|}{ Argentine Republic } & 1927 & Government (Universidad Nacional de La Plata). \\
\hline \multirow{4}{*}{$\begin{array}{l}\text { Argentine } \\
\text { Australia } \\
\text { Belgium } \\
\text { Canada } \\
\text { Chile }\end{array}$} & $\ldots$ & $\ldots$ & 1939 & Australian Academy of Science. \\
\hline & $\ldots$ & $\ldots$ & 1920 & Académie Royale de Belgique. \\
\hline & ... & $\ldots$ & 1920 & Department of Mines and Technical Surveys. \\
\hline & $\ldots$ & $\ldots$ & 1947 & $\begin{array}{l}\text { Observatorio Astronómico de la Universidad de Chile, Santiago de } \\
\text { Chile. }\end{array}$ \\
\hline China & $\ldots$ & ... & 1935 & National Committee of Astronomy, Nanking. \\
\hline Czechoslo & vakia & $\ldots$ & 1922 & Academy of Sciences, Prague. \\
\hline Denmark & $\ldots$ & $\ldots$ & 1922 & Kongelige Danske Videnskabernes Selskab, Kфbenhavn. \\
\hline Egypt & $\ldots$ & $\ldots$ & 1925 & Government. \\
\hline Eire $v$ & $\ldots$ & $\ldots$ & 1947 & Dublin Institute for Advanced Studies. \\
\hline Finland & $\ldots$ & $\ldots$ & 1948 & Académie des Sciences et Lettres, Helsinki. \\
\hline France & $\ldots$ & ... & 1920 & Académie des Sciences, Paris. \\
\hline Germany & $\ldots$ & $\ldots$ & 1951 & Astronomische Gesellschaft, Hamburg-Bergedorf Sternwarte. \\
\hline Great Bri & itain & $\ldots$ & 1920 & Royal Society, London. \\
\hline Greece & $\ldots$ & ... & 1920 & Académie d'Athènes, Athens. \\
\hline Hungary & $\ldots$ & $\ldots$ & 1947 & Hungarian Academy of Sciences, Budapest. \\
\hline India & $\ldots$ & $\ldots$ & 1946 & Ministry of Natural Resources and Scientic Research, New Delhi. \\
\hline Israe $i$ & ... & $\ldots$ & 1954 & The Research Council of Israel. \\
\hline Italy & $\ldots$ & $\ldots$ & 1921 & Consiglio Nazionale delle Ricerche, Roma. \\
\hline Japan & $\ldots$ & $\ldots$ & 1920 & National Research Council, Tokyo. \\
\hline Lebanese & Repub] & & 1954 & National Lebanese Committee for Astronomy. \\
\hline Mexico & $\ldots$ & $\ldots$ & 1921 & National University of Mexico. \\
\hline Netherlan & & ... & 1922 & $\begin{array}{l}\text { Koninklijke Nederlandsche Akademie van Wetenschappen, Am- } \\
\text { sterdam. }\end{array}$ \\
\hline Norway & ... & ... & 1922 & Det Norske Videnskaps-Akademi, Oslo. \\
\hline Poland & ... & $\ldots$ & 1922 & Polska Akademia Nauk, Warszawa. \\
\hline Portugal & $\ldots$ & $\ldots$ & 1924 & Government. \\
\hline Roumania & & $\ldots$ & 1928 & Comitetul National Astronomic. \\
\hline South Afr & & ... & 1938 & The Council for Scientific and Industrial Research, Pretoria. \\
\hline Spain & $\ldots$ & ... & 1922 & Academia de Ciencias Exactas, Madrid. \\
\hline Sweden & ... & $\ldots$ & 1925 & Kungl. Vetenskapsakademien, Stockholm. \\
\hline Switzerlan & & ... & 1923 & Schweizerische Naturforschende Gesellschaft, Bern. \\
\hline United St: & cates & ... & 1920 & National Research Council, Washington. \\
\hline U.S.S.R. & $\ldots$ & ... & 1935 & Academy of Sciences of the U.S.S.R., Moscow. \\
\hline Vatican C & ity Sta & & 1932 & Pontifica Accademia delle Scienze i Nuovi Lincei, Roma. \\
\hline Venezuela & & $\ldots$ & 1953 & Academia de Ciencias Fisicas Matematicas y Naturales, Caracas. \\
\hline Yugoslavi & & ... & 1935 & Conseil des Académies de la R.F.P.Y., Belgrade., \\
\hline $\begin{array}{c}-10 \\
\text { is }\end{array}$ & & $\cdots$ & & 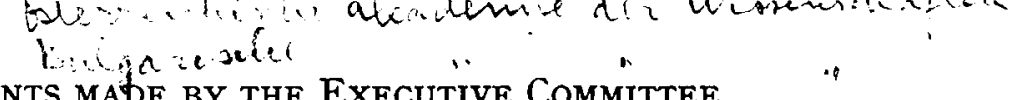 \\
\hline
\end{tabular}

Prof. T. G. Cowling was appointed President of Commission 35 after Prof. S. Chandrasekhar resigned from this function.

Prof. J. H. Oort was appointed President of Sub-Commission 33a, which will continue the work started at the Groningen symposium on 'Co-ordination of Galactic Research'.

Prof. B. Lindblad and Prof. P. Th. Oosterhoff represented the I.A.U. at the sixth General Assembly of I.C.S.U. in I952.

A U IX 
At the fifth and sixth meetings of the Executive Board of I.C.S.U. in I953 and r954 the I.A.U. was represented by Dr A. Couder and Prof. P. Th. Oosterhoff and by Sir Harold Spencer Jones and Prof. P. Th. Oosterhoff respectively.

Prof. E. Dingle represented the I.A.U. at the General Assembly of I.U.H.S. in I953, while the I.A.U. was represented in I954 by Dr J. L. Pawsey at the General Assembly of U.R.S.I. and by Prof. A. Danjon and Sir Harold Spencer Jones at the General Assembly of I.U.G.G.

In I954 Dr P. Bourgeois and Sir Harold Spencer Jones represented the I.A.U. at a meeting of the International Latitude Service.

Prof. A. Danjon represented the I.A.U. in I954 at the celebration of the centenary of Henri Poincaré's birthday.

The General Secretary represented the I.A.U. in I954 at the opening ceremony of the renewed Pulkovo Observatory.

The Executive Committee appointed Prof. A. Danjon and Sir Harold Spencer Jones to represent the I.A.U. in I.C.S.U.'s Special Committee for the International Geophysical Year (C.S.A.G.I.).

\section{Meetings of the Executive Committee}

After the Rome General Assembly the Executive Committee met only once, namely in Liège, on I2-I4 July I954.

The following took part in the meetings: O. Struve (President), V. A. Ambartsumian (Vice-President), A. Couder (Vice-President), E. Rybka (Vice-President), P. Swings (Vice-President), R. v. d. R. Woolley (Vice-President), B. Lindblad (former President), B. Strömgren (former General Secretary), P. Th. Oosterhoff (General Secretary) and in advisory capacity A. Danjon, Sir Harold Spencer Jones, P. G. Kulikovsky, J. H. Oort, G. A. Shajn and F. J. M. Stratton. The agenda of the meeting included the following items: financial status of the I.A.U. and grants-in-aid from U.N.E.S.C.O.; future symposia and the publication thereof; the next General Assembly and the assembly of I958; the question of co-option and nomination; discussion of plans for a change in the organization of the Union and its standing commissions.

In some financial matters, which could not be postponed until the next General Assembly, a decision was taken. The Executive Committee allocated a grant of \$rooo to the Comite de Gestion pour les Tables de Constantes for the 4 th and 5 th volumes, which are of considerable interest to astrophysicists. Furthermore it allocated a grant of $\$ 500$ for the publication of the symposium on 'Co-ordination of Galactic Research' held in I953 and a grant of $\$ 560$ for the publication of the symposium on 'Gas-dynamics and Interstellar Clouds' held in I953 also. As the grant of $\$ 2000$ allocated in I95I for the publication of the Quarterly Bulletin on Solar Activity had been spent and the continuation of this Bulletin had become difficult, a new grant of $\$ 1000$ was allocated to cover the expenses until the next general assembly.

The time of the ninth General Assembly, to be held in Dublin, was fixed as from 29 August until 5 September 1955 .

It was decided that three symposia should be organized on this occasion, two during the assembly and one shortly before. The first, to be held on 25, 26 and 27 August r955 at the Jodrell Bank Experimental Station near Manchester, will deal with Radioastronomy and will be organized by Lovell (chairman), Hagen, Laffineur, Pawsey and van de Hulst (secretary).

During the assembly there will be a symposium on 'Non-stable Stars', to be organized by Ambartsumian (chairman), Swings and Herbig, and one on 'A Comparison of the large-scale Structure of the Galactic System with that of other Stellar Systems', to be organized by Oort (chairman), Baade, Pawsey and van de Hulst. Furthermore, four Joint Discussions will take place during the Dublin meeting. The following topics and organizing committees were chosen: Turbulence in Stellar Atmospheres (Greenstein); Fundamental Stars (Zverev, Heckmann, Scott); Solar Flares (Öhman, Pawsey) and Photo-electric Image Tubes and their Astronomical Applications (Baum). 
It was also decided that henceforth the symposia, organized by the I.A.U., will be published in a new separate series of publications. The first volume in this series will be the report on the Groningen symposium on 'Co-ordination of Galactic Research', the second that on the Cambridge symposium on 'Gas-dynamics and Interstellar Clouds'.

In order to facilitate the task of the Nominating Committee the Executive Committee approved the following rules for the nominating procedure:

I. Twelve months before the General Assembly adhering organizations will be asked to submit proposed changes in membership. A closing date fixed at nine months before the Assembly will be given and if no reply has been received by the closing date it will be presumed that the organization in question is not proposing any changes as far as its nationals are concerned.

2. The General Secretary will then prepare a list of proposed membership incorporating the changes proposed under ( $\mathrm{I}$ ) and it will be circulated to Presidents of Commissions. A closing date will be given and if a President has not replied by the closing date he will be presumed to have no objection to the suggested list. The closing date will be six months before the General Assembly.

3. Any suggestions made by Presidents of Commissions will be forwarded to the adhering organizations affected with a closing date for their reply. If no reply is received, it is to be presumed that the adhering organization concerned agrees to the changes suggested by the Presidents. The closing date will be three months before the General Assembly.

4. At the General Assembly the nominating committee will be concerned only with: (a) settling cases of disagreement between Presidents of Commissions and adhering organizations; $(b)$ with considering any individual case expressly remitted to it by the Executive. Late nominations or deletions under (I), (2) or (3) above will not be considered and it will be an instruction to the Chairman from the Executive that any such will be ruled out of order.

During the discussion of the present organization of commissions and of the rules for membership, several detailed proposals were made, which would require a change of the by-laws. In view of the complexity of this problem the Executive Committee nominated an informal committee which should try to prepare definite proposals for the Dublin General Assembly.

The Executive Committee approved the formation of two new sub-commissions, which will continue the work started at the Groningen symposium on 'Co-ordination of Galactic Research'. The new sub-commissions are:

33a: Oort (President), Blaauw (Secretary), Baade, Lindblad, Parenago and van Rhijn (members).

27a: Members Baade, Blaauw, Kukarkin and Oosterhoff.

The Executive Committee decided to discontinue Sub-Commission $13 a$, which had been recommended at the Rome General Assembly in 1952 for collecting and distributing of information about future eclipses.

At present the I.A.U. is represented in three Joint Commissions of the International Council of Scientific Unions, as follows:

Joint Commission on the Ionosphere: Prof. V. G. Fesenkov, Prof. D. H. Menzel and Dr J. L. Pawsey.

Joint Commission on Solar and Terrestrial Relationships: Dr L. d'Azambuja, Mr H. W. Newton, Dr G. Righini, Prof. M. Waldmeier.

Joint Commission on Spectroscopy: Prof. B. Edlén, Prof. G. Herzberg, Dr W. F. Meggers, Dr C. E. Moore-Sitterly, Prof. P. Swings.

With regard to the financial status of the Union and the U.N.E.S.C.O. grants further information is given below in this Report. 


\section{Deceased Members}

The Executive Committee regret to record the loss by death of the following members of the Union:

Dr B. A. Asplind, Member of Commission 20. Died 30 September 1954.

Prof. T. Banachiewicz, Member of Commissions 17, 20, 27, 31. Died 17 November 1954.

W. Benitez e Inglott, Member of Commissions 4, 23. Died 22 December 1954.

Prof. J. Chazy, Member of Commissions 4, 7. Died 9 March 1955.

Prof. A. O. Colacevich, Member of Commissions 9, 29. Died 25(?) August 1953.

Prof. E. de Caro, Member of Commission 23. Died 2 March r954.

Prof. L. F. Erro, Member of Commission 29. Died 18 January r 955.

Prof. E. Esclangon, Member of Commission 23. Died 28 January 1954.

G. Fournier, Member of Commission I6. Died I December I954.

Dr A. Gatterer, S.J., Member of Commissions 29, 29c. Died I7 February 1953.

Miss Dr V. F. Gaze, Member of Commissions 29, 29c. Died 3 October 1954.

Prof. L. Gialanella, Member of Commission 16. Died ro January 1954.

Dr W. Grotrian, Member of Commissions ro, 13. Died 3 March 1954.

Dr E. Hubble, Member of Commissions 28, 4I. Died 28 September 1953.

Prof. A. O. Leuschner, Member of Commission 20. Died June I953.

S. Lomoine, Member of Commission 40.

Dr H. Mineur, Member of Commissions 7, 33, 37. Died 7 May 1954.

Dr F. J. Neubauer, Member of Commissions 5, 30a. Died 16 September 1952.

Prof. A. J. Orlov, Member of Commission 19. Died 29 January 1954.

R. M. Stewart, Member of Commission $3 \mathbf{r}$.

Dr J. Tinoco, Member of Commission 31. Died October 1953.

Prof. L. Volta, Member of Commission 4I. Died 7 October 1952.

Dr F. E. Wright, Member of Commission I6. Died 25 August I953.

\section{New Members}

After the meeting in Rome the following were co-opted by the various Commissions under By-Law IV, I5:

H. Abt (29), L. Biermann (I5), A. Bruzek (II), J. W. Evans (I I), M. W. Feast (29, 29c), V. C. A. Ferraro (35), A. Fresa (42), H. Gollnow (30), A. Gougenheim (18), G. Herzberg (I5), J. Junkes (29, 29c), A. König (24), W. Lohmann (37), R. A. Lyttleton (15), V. Maître (8), W. Markowitz (I7), F. D. Miller (I 5), B. Y. Mills (40), M. G. J. Minnaert (I5), R. Müiller (II), L. Münch (29), D. J. K. O'Connell (42), G. Pels (20), L. Perek (42), E. Schoenberg (34), Miss R. Szafraniec (27), P. Tempesti (27), A. van Hoof (42), P. Wellmann (42).

\section{Symposia}

During the eighth General Assembly at Rome three symposia have been held on 'Stellar Evolution', on 'Astronomical Instrumentation' and on 'Problems of Astrometry of Faint Stars'. Together with a joint discussion on 'Spectra of Variable Stars', these symposia have been reported in detail in the eighth volume of the Transactions of the I.A.U.

A symposium on 'Co-ordination of Galactic Research', organized by Oort (chairman), Baade, Bok, Fehrenbach, Lindblad, W. W. Morgan and Parenago was held near Groningen, 22-27 June I953. It was attended by twenty-seven astronomers. A report on this symposium was published in the spring of 1955 as the first volume of the new I.A.U. symposium series. 
A symposium on 'Gas-dynamics and Interstellar Clouds' was held in Cambridge (England), 6-II July I953, under the combined auspices of the International Union of Theoretical and Applied Mechanics and the International Astronomical Union. Oort, Hoyle, Spitzer and van de Hulst were members of the organizing committee for the I.A.U. The report on this symposium, which was attended by thirty-three invited members of the I.A.U., was published early in I955 as the second volume of the new symposium series.

The I.A.U. is very grateful to U.N.E.S.C.O. for allocating important grants-in-aid towards travelling and subsistence expenses in connexion with these two symposia.

The symposia planned for the ninth General Assembly have already been mentioned in the section on meetings of the Executive Committee.

\section{U.N.E.S.C.O. GRANTS, I952, I953 AND I954}

The following grants have been allocated to the I.A.U. by U.N.E.S.C.O. for the purposes mentioned in the breakdown given below: $\$ 14,300$ for 1952 , $\$ 14,750$ for 1953 and $\$ 14,010$ for 1954 .

1952

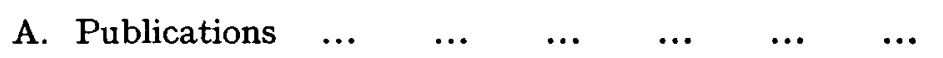
Requested Allocated

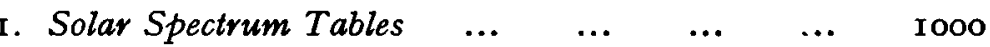

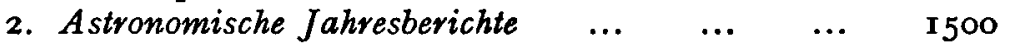

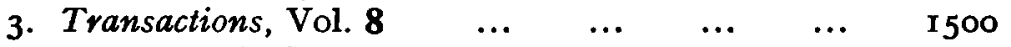

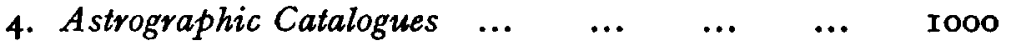

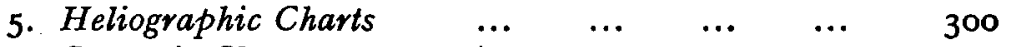

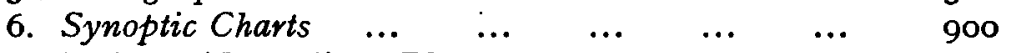
7. Ephemerides, Minor Planets $\quad \ldots \quad$... $\quad \ldots \quad$... 800

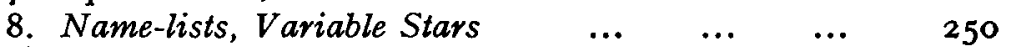
9. Ephemerides, Eclipsing Binaries ... $\quad \ldots \quad \ldots \quad 300$

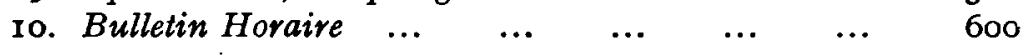
$\$ 8150$
B. Symposia $\quad \ldots \quad \begin{array}{llllllllll} & \ldots & \ldots & \ldots & \ldots & \ldots & \ldots & \ldots & 2500\end{array}$
Co-ordination of Galactic Research

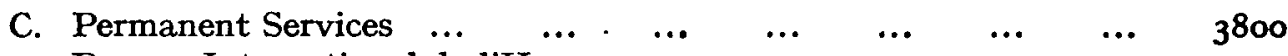
Bureau International de l'Heuro

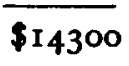

The breakdown of grant A was left entirely to the discretion of the I.A.U. Grant B of $\$ 2500$ was transferred by virement to r953 for the same purpose.

However, in I 952 an additional sum of $\$ 7650$ was available, which had been transferred by virement from I95I. It consisted of the following items:

(a) Meetings of Committees

I. Travel expenses officers of the I.A.U., General Assembly $\quad$ I800

2. Travel expenses 'young astronomers', General Assembly 2000

(b) $\begin{array}{llllllllll}\text { Symposia } \ldots & \ldots & \ldots & \ldots & \ldots & \ldots & \ldots & \ldots & 3^{8} 5^{\circ}\end{array}$

I. Stellar Evolution

2. Astronomical Instrumentation

$\$ 7650$

Of grant $(b)$ a sum of $\$ 1850$ remained unspent, which was returned to I.C.S.U. 


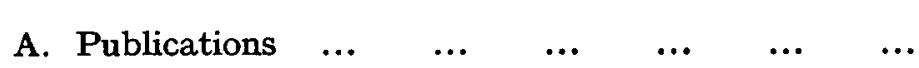

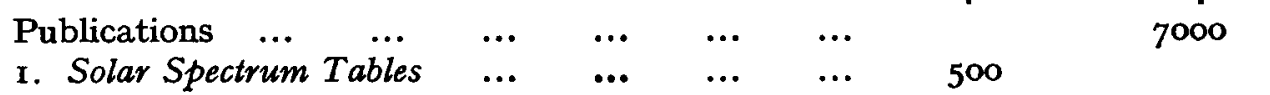

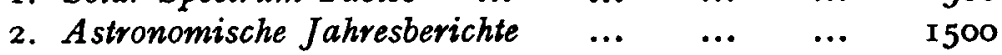
3. Transactions, Vol. $8 \quad \ldots \quad$... $\quad \ldots \quad$... 2000

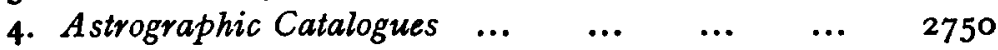

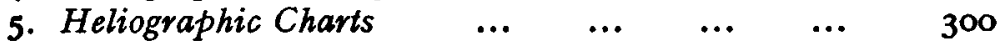

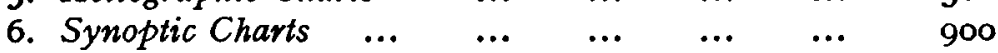
7. Ephemerides, Minor Planets $\quad \ldots \quad$... $\quad \ldots .80$

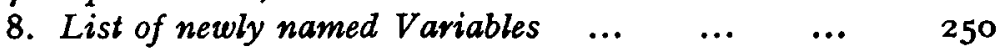

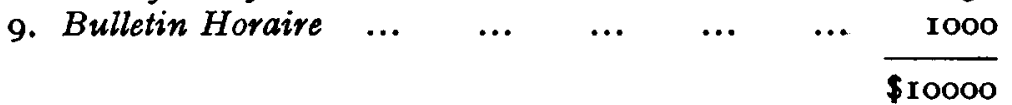

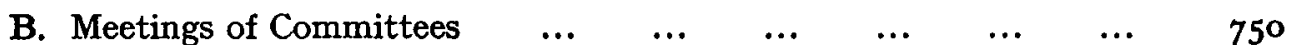
Travel expenses, Executive Committeo

C. Symposia

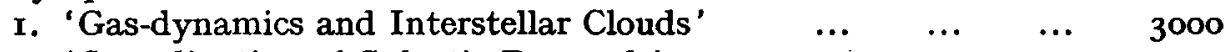

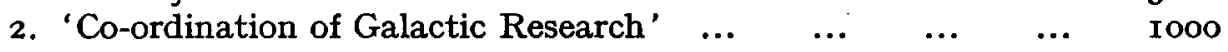

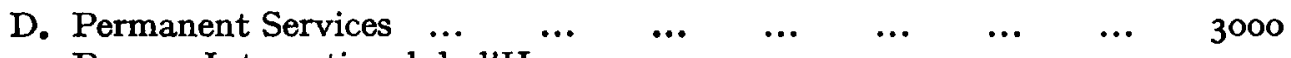

Bureau International de l'Heure

The breakdown of grant A was left to the discretion of the I.A.U.

Grant B was transferred by virement to 1954 for the same purpose.

For the symposium on 'Gas-dynamics and Interstellar Clouds', which took place under the combined auspices of I.U.T.A.M. and I.A.U., another grant of $\$ 3000$ was available, which had been allocated by U.N.E.S.C.O. to I.U.T.A.M.

For the symposium on 'Co-ordination of Galactic Research' a total of $\$ 3500$ was available, consisting of the grant of $\$ 1000$ mentioned above and of the grant of $\$ 2500$ for I952, which had been transferred by virement.

\section{I954}

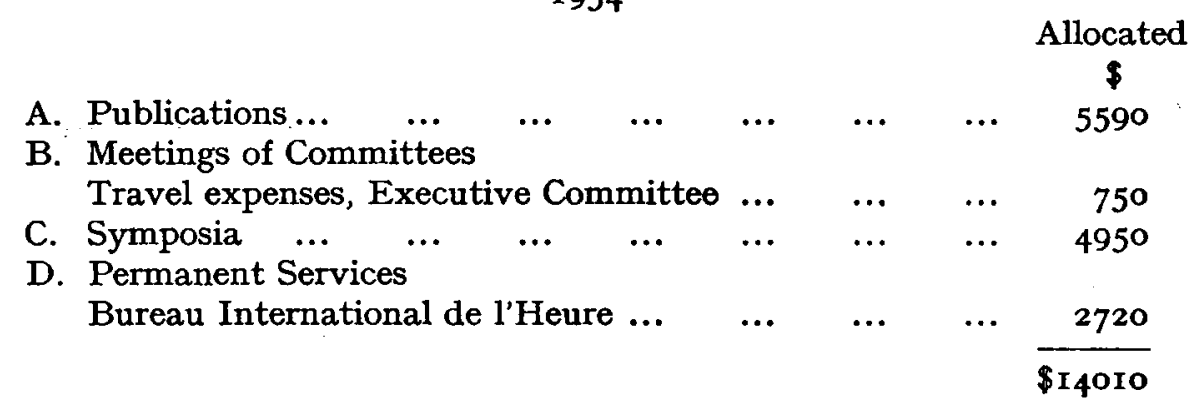

The original grant for item A was $\$ 5340$, but later in the year an extra $\$ 250$ were allocated for this purpose. No specification of the publications was required by U.N.E.S.C.O.

For the meeting of the Executive Committee a sum of $\$ 500$ was available, consisting of the $\$ 75^{\circ}$ mentioned above, together with $\$ 75^{\circ}$ transferred by virement from I953.

As the I.A.U. did not organize any symposia in 1954 a virement for the same purpose to I955 has been applied for.

The financial support given by U.N.E.S.C.O. to the I.A.U. has been of the greatest importance to this Union. The I.A.U. is greatly indebted to U.N.E.S.C.O. and to I.C.S.U. and to their officers who have given most efficient help in connexion with these grants. 
The I.A.U. is especially grateful to Dr Ronald Fraser, administrative secretary of I.C.S.U. and to Prof. A. V. Hill, General Secretary of I.C.S.U.

Several large and small volumes have been published during the period covered by this report under the auspices and with financial aid from the I.A.U. The financial aid received from U.N.E.S.C.O. for this activity is herewith gratefully acknowledged.

\section{List of Publications}

Vol. 8 of the Transactions of the I.A.U.

Commission 5:

Astronomical News Letters

Commission Io: Quarterly Bulletin on Solar Activity Heliographic Charts of the Photosphere

Bok, Kourganoff

Waldmeier

Waldmeier

Commission I I:

Cartes Synoptiques de la Chromosphere

d'Azambuja

Commission 20:

Ephemerides and Circulars, Minor Planet Center, Cincinnati Herget

Commission 23:

Astrographic Catalogue:

Edinburgh Section, Zone $-3^{\circ}$ and Oxford-Potsdam, Zones

$+32^{\circ}$ and $+33^{\circ}$

Commission 24:

Gexeral Catalogue of Trigonometric Stellar Parallaxes Jenkins

Commission 26:

Bulletin d'Information

Muller

Commission 27:

English version of Introduction and Remarks from the third and fourth supplement to the General Catalogue and from the catalogue of Suspected Variables

Kukarkin, Parenago

Commission $3 \mathrm{x}$ :

Bulletins Horaires du Bureau de l'Heure Danjon

\section{INCOME AND EXPENDITURE}

At the General Assembly in Rome in September I952 it was decided that the unit of subscription for the years $1952-55$ be fixed at 500 gold francs, the gold franc being defined in accordance with the Statutes of the International Council of Scientific Unions, Vol. 3, p. I07, I937, as $0.2903225 \mathrm{~g}$. fine gold, or 0.3266 U.S. dollar.

The detailed reports of the accounts of the I.A.U. in different currencies for the years 1952-54, which are to be found at the end of this report, differ in two respects from the previous accounts. According to a decision of the General Assembly of 1952 the financial year now covers the period from I November until 3I October. Consequently the accounts for the year 1952 cover a period of ten months only, namely from I January until 3I October I952. From the last date onward the new financial year has been adopted, and the present accounts close on 3r October 1954.

According to a decision by the Executive Committee, taken at its meeting in Liège, in 1954 the accounts in gold francs have been abandoned in the present report. Instead of these, accounts are now given in Italian lires and in French francs. As the I.A.U.'s bank account in Paris for the French francs was opened in I948, detailed annual accounts are given in this report from I948 until I954, although the data for the years I948-5I can be found in less detail in the gold francs accounts in Vol. 8 of the Transactions. 
In order to simplify the financial administration, the accounts in Danish and in Swedish crowns have been closed. The account in lires was used only during the year of the eighth General Assembly.

On I November I954 the unexpended balance was about $\$ 94,500$. Part of this amount, however, must be considered as committed for publications and for other purposes or as a consequence of virements of U.N.E.S.C.O. grants from the year I954 to the year 1955. The total amount committed is estimated to be about $\$ 29,000$. Therefore the net balance is approximately $\$ 65,500$. The increase of the balance from about $\$ 43,000$ on I January 1952 is due mainly to the fact that nearly all the arrears in subscription have now been paid. At present the total annual income from subscriptions equals 120 units or $\$ 19,596$. As the average annual subvention from U.N.E.S.C.O. during the last years amounted to about $\$ 14,000$, the available balance would allow the I.A.U. to continue its present activities for about five years, if U.N.E.S.C.O. grants were to be discontinued. The financial situation of the I.A.U. may therefore be considered as satisfactory. The co-operation of National Committees and Adhering Organizations in these financial matters has been most helpful and is herewith gratefully acknowledged.

\section{Total InCOME AND EXPENDITURE, I952-54}

During the period covered by this report the rate of exchange between the various currencies in which payments were received and made has been very stable. For the conversion into dollars the following values have been used:

$$
f \mathrm{I}=\$ 2.8 ; \$ \mathrm{I}=350 \text { French francs; } \$ \mathrm{I}=3.80 \text { guilders; } \$ \mathrm{I}=625 \text { lires. }
$$

The subscriptions received, including arrears, are as follows:

$$
\begin{array}{ccc}
195^{2} & 1953 & 1954 \\
\$ 19460.81 & \$ 16003.40 & \$ 34739.59
\end{array}
$$

The large income in 1954 is due to the fact that in this year practically all the outstanding arrears, several of which dated still from the years of war, have been paid.

The amounts paid in I952-54 on annual grants (cf. Trans. I.A.U. 8, p. 65) are given in the following table:

\begin{tabular}{lr} 
& \multicolumn{1}{c}{} \\
Commission 6 (Bureau des Télégrammes) & I 176 \\
Commission 10 (Cartes héliographiques de la photosphère) & 954 \\
Commission I I (Cartes synoptiques) & I764 \\
Commission 20 (Centre des Petites Planètes, Cincinnati) & Ior2 \\
Commission 27 (Liste des Noms d'Etoiles Variables) & 962 \\
Commission 3I (Bureau International de l'Heure) & I7574 \\
- Commission 38 (Echange des Astronomes) & 6706 \\
\cline { 2 - 2 } & Total $\$ 30148$
\end{tabular}

\section{Remarks}

Commission II: Paid for two years only, as in former years the I.A.U. subventions, actually paid, were in excess of the amounts voted.

Commission 20: This sum proved adequate for the operation of the centre.

As the breakdown of the U.N.E.S.C.O. subventions for the category of publications was left to the discretion of the I.A.U., it is not really possible to say which fraction of each subvention given in the above table was reimbursed by U.N.E.S.C.O.

For the category of publications the I.A.U. received from U.N.E.S.C.O. a sum of $\$ 20,590$, but this grant was also used to cover part of the expenses for Vol. 8 of the Transactions, Solar Spectrum Tables, Astrographic Catalogues and for the reduction in the price of the Astronomische Jahresberichte, all of which will be mentioned below.

The subvention for the Bureau International de l'Heure has been reimbursed by U.N.E.S.C.O. to an amount of $\$ 9520$. 
The following special subventions were paid:

$\begin{array}{llllllll}\text { Commission } 5 \text { (Astronomical News Letters) } & \ldots & \ldots & \ldots & \ldots & \ldots & 600\end{array}$

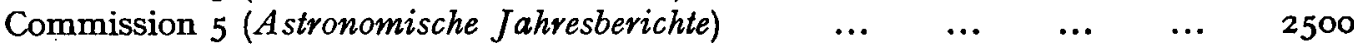

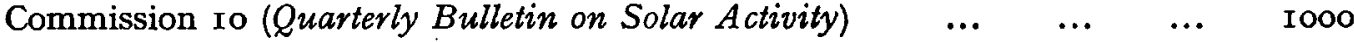

$\begin{array}{lllll}\text { Commission I5 (Reproduction des clichés, spectres cométaires) } & \ldots & \ldots & 523\end{array}$

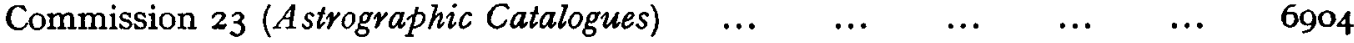

Commission 23 (Elements des clichés de la zone $+20^{\circ} \grave{a}+25^{\circ}$. Heckmann) 1500

Commission 24 (Publication de la 3ième edition du Parallax Catalogue) ... I 500

Comité de Gestion (Tables de Constantes) $\quad \ldots \quad$..

Remarks

Total $\$ 15527$

Commission 5 (Astronomische Jahresberichte)-This subvention was allotted by the Executive Committee in I951.

Commission ro (Quarterly Bulletin on Solar Activity)-This subvention was allotted by the Executive Committee in 1954.' (See report, meetings of Executive Committee in the present volume.)

The subvention of $\$ 1000$ for the publication of Vols. 4 and 5 of Tables de Constantes was also allotted by the Executive Committee in 1954. (See report of meetings of Executive Committee in the present volume.)

The total expenses on the Bureau of the Union amounted in this period to $\$ 30,566$. Several expenses, however, were partly reimbursed by U.N.E.S.C.O. The following table shows the expenses in more detail, together with the subventions received from U.N.E.S.C.O.

Paid by Reimbursed by I.A.U. U.N.E.S.C.O.

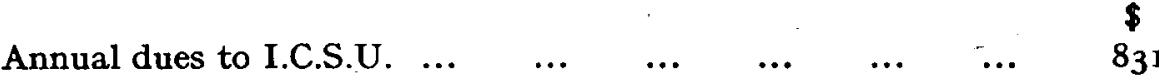
Draft Report and Transactions, Vol. 8 ... $\quad \ldots \quad \ldots \quad \ldots \quad \therefore \quad 9476$ Travel expenses, Rome General Assembly, including Symposia 6705

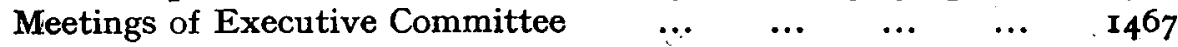
Symposium: 'Co-ordination of Galactic Research' $\quad \ldots \quad$.. 3490 Symposium: 'Gas-dynamics and Interstellar Clouds' ... $\quad \ldots .2995$ Meeting of Committee of International Latitude Service $\quad \ldots \quad 156$ Grant allocated to International Latitude Service $\quad \ldots \quad \ldots \quad 300$ General Secretariat

Total $\frac{5146}{\$ 30566}$
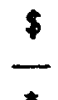

5662 1366 3490 295 I

$\$ 13469$

* See remark on publications above.

The following subventions, voted by the General Assembly, have not yet been paid, but should be considered as commitments:

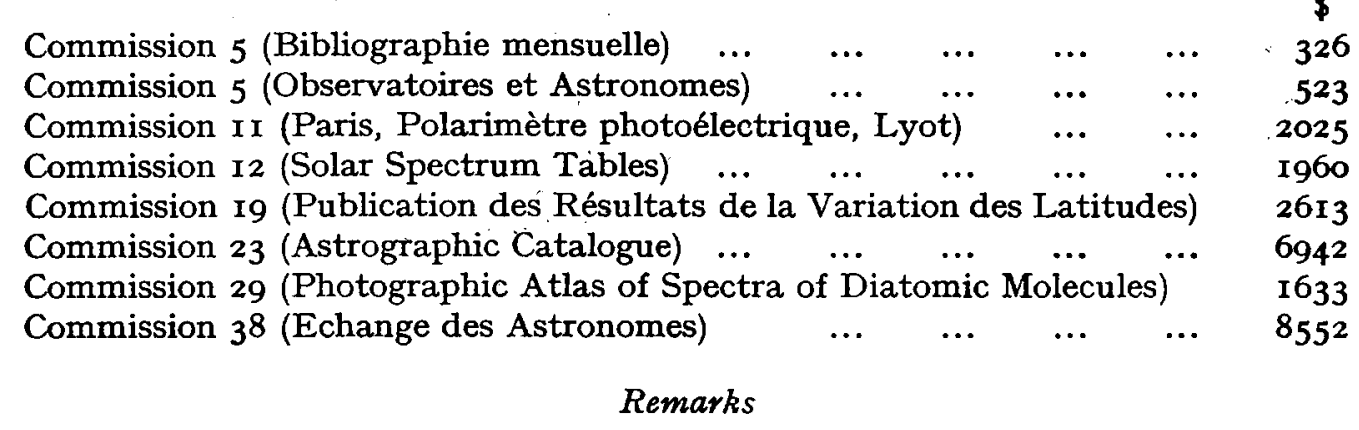

It is to be expected that the grant allocated to Commission 29 will not be required. 


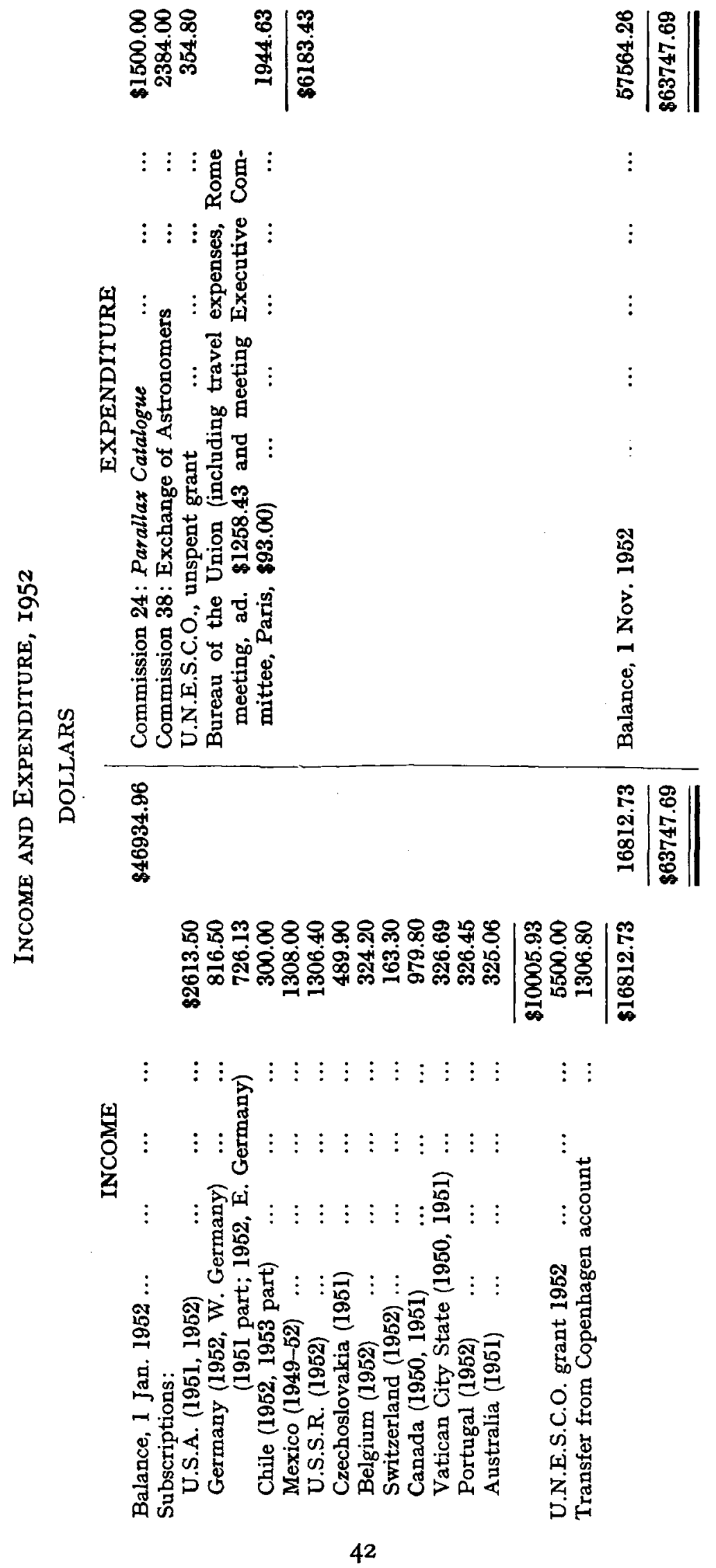




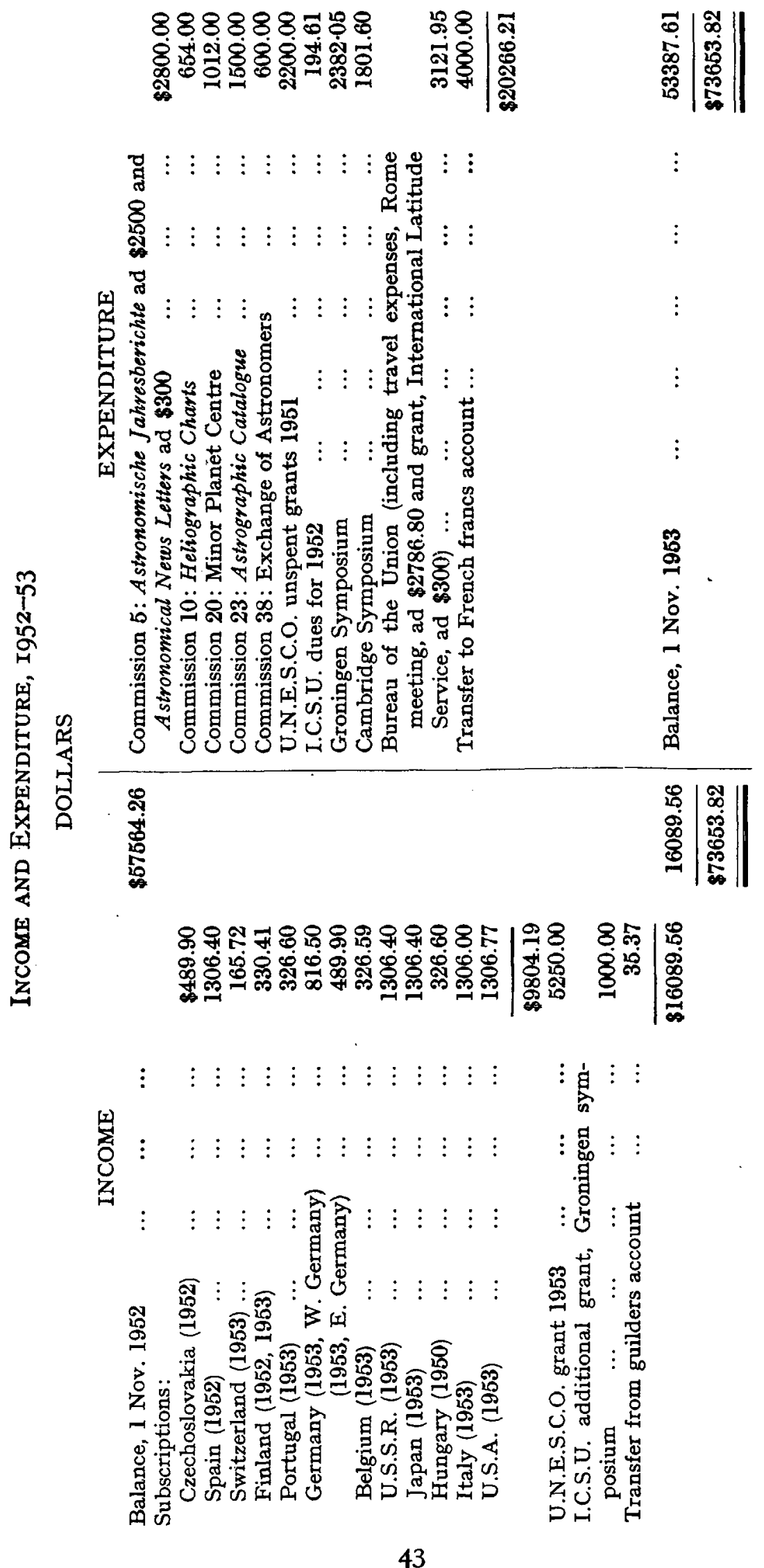




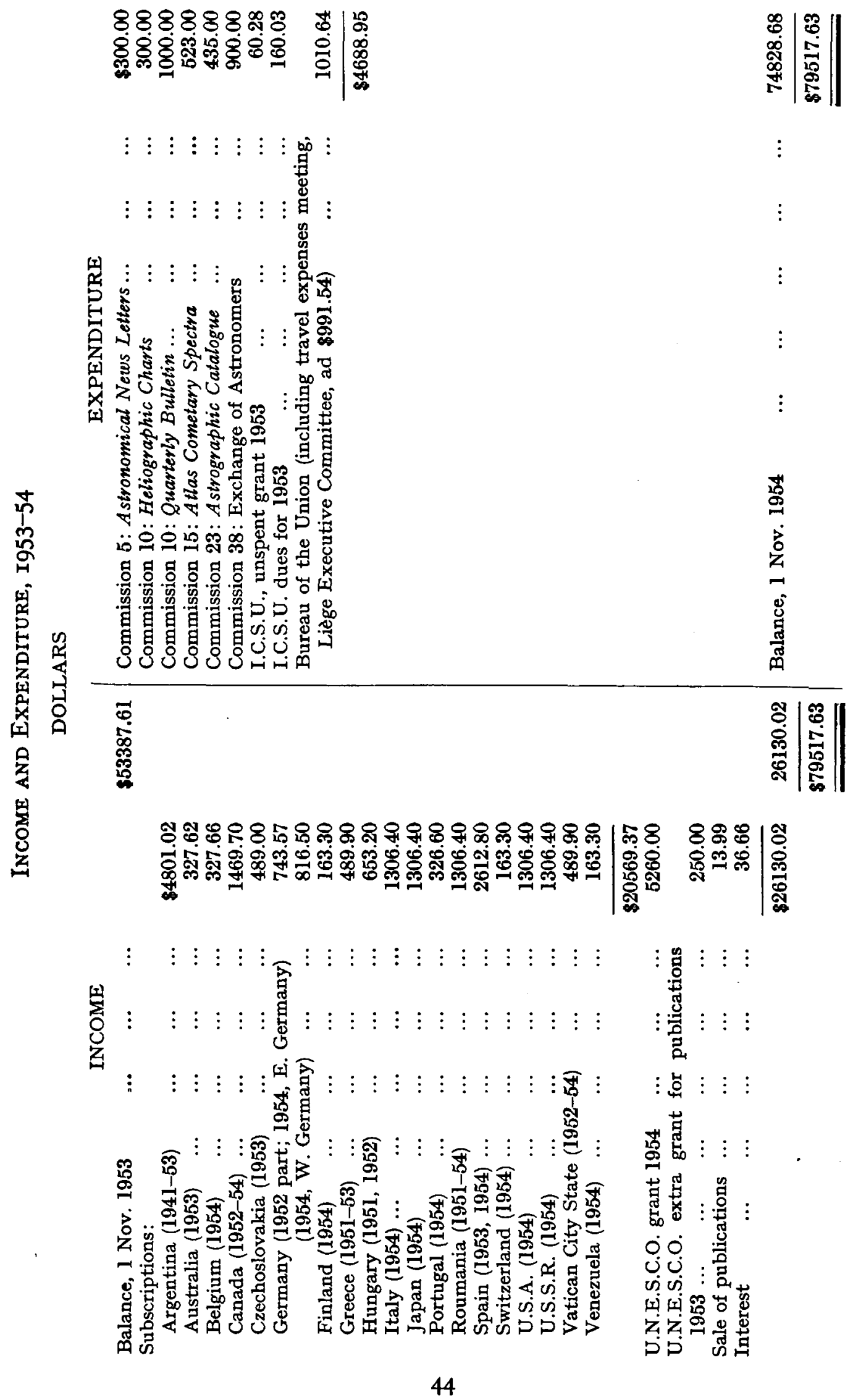




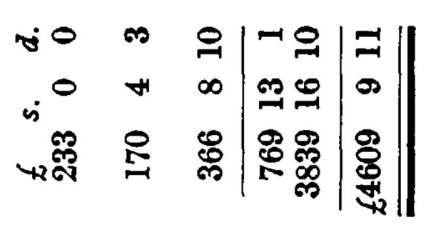
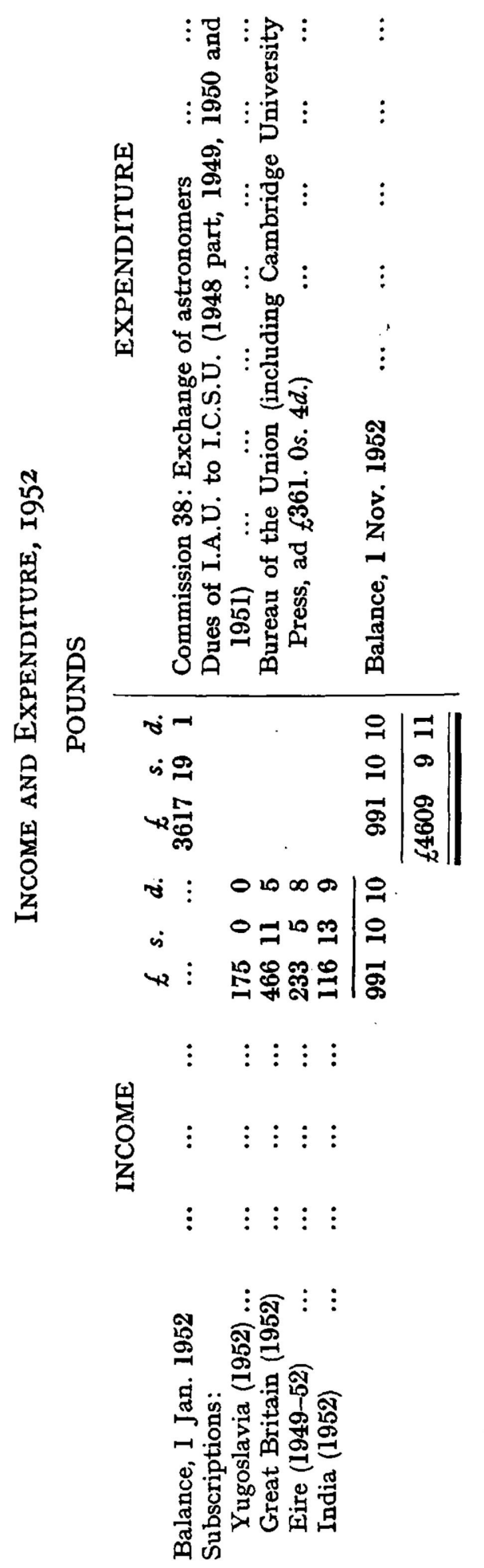

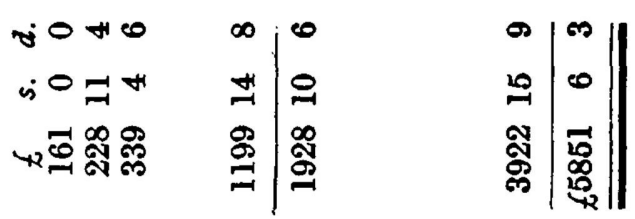

$\vdots \vdots \vdots$ 幽

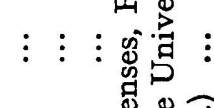

点

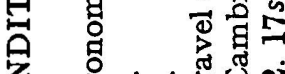

药

齐

岁: : : 窇守

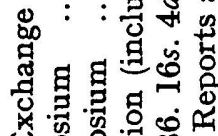

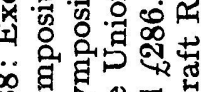

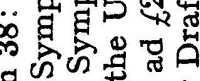

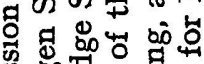

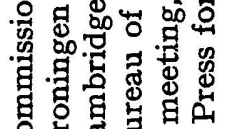

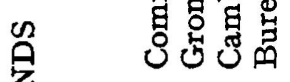

空

位

案

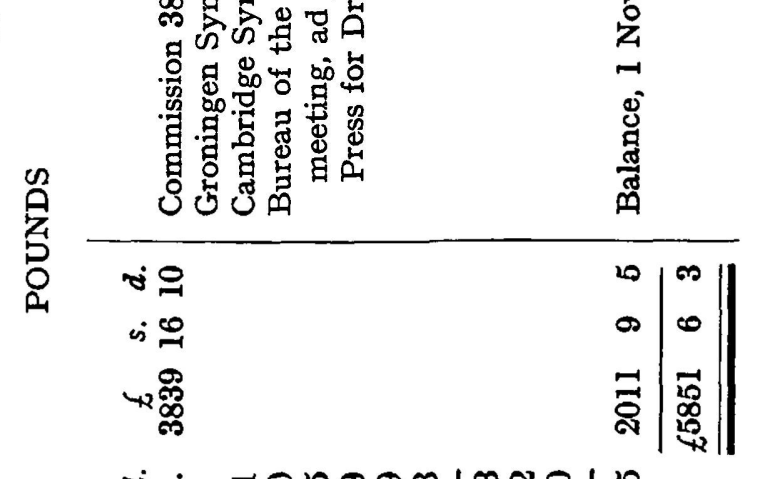

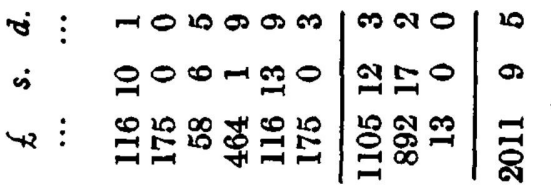

뇔

$\vdots \quad \vdots \vdots \vdots \vdots \vdots \vdots \vdots$

$\vdots \quad \vdots \vdots \vdots \vdots \vdots \vdots \quad \vdots \vdots$

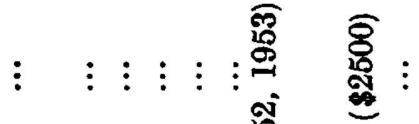

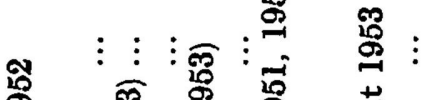

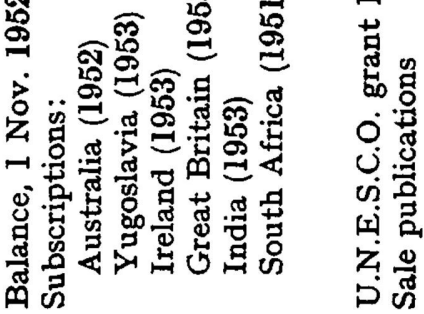




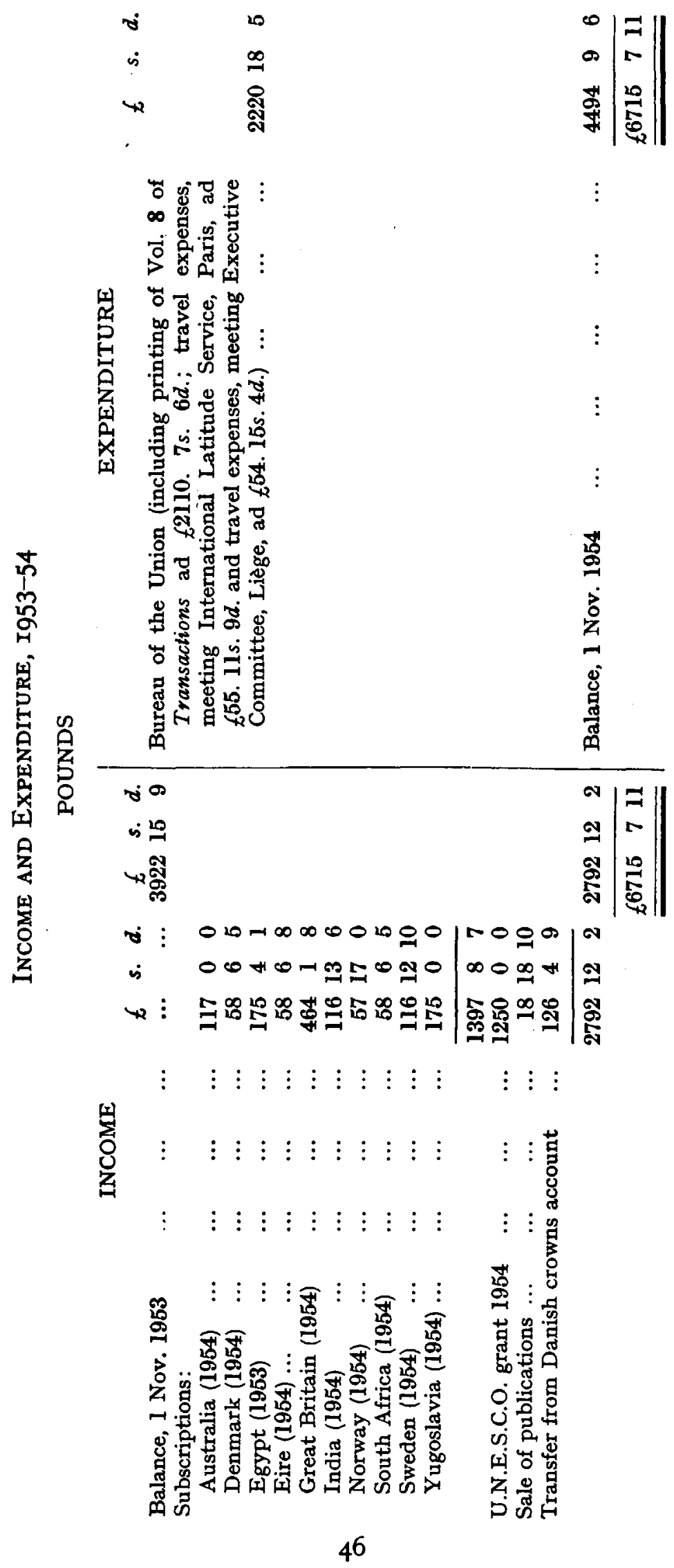




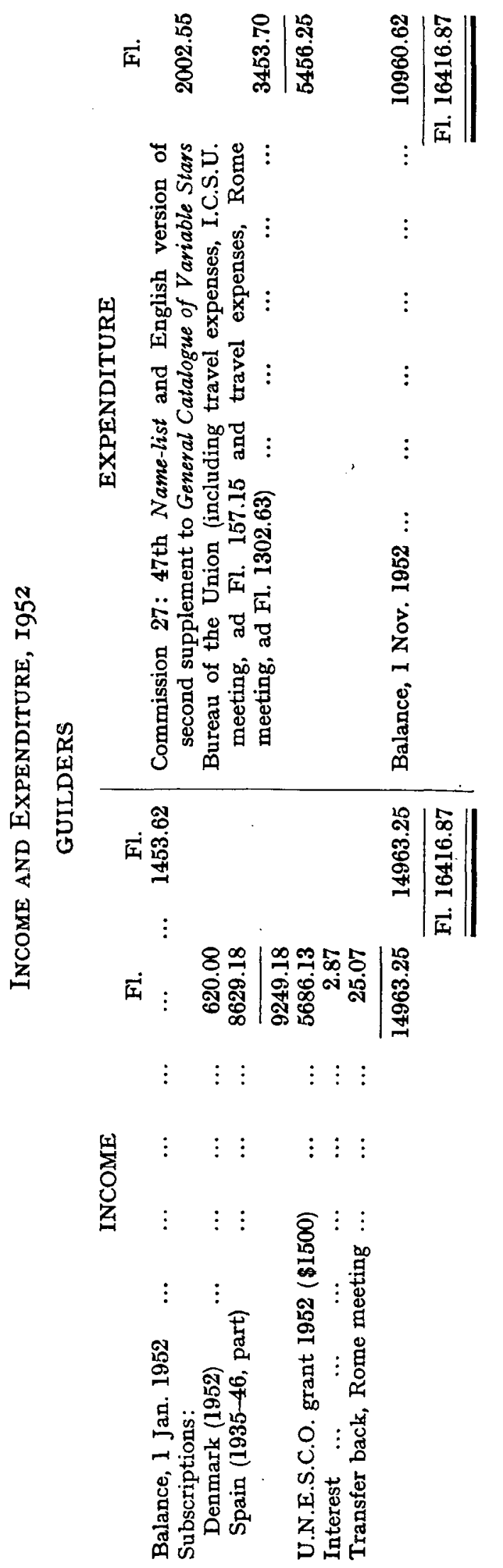

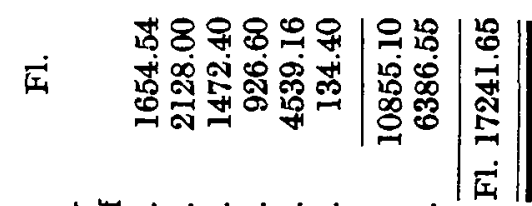

बे山

염명

考㻤

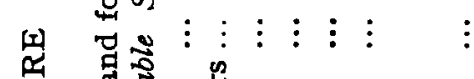

点苟害 离

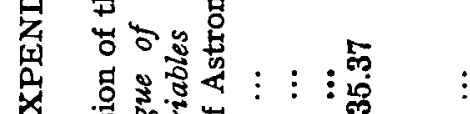

(I)

का है

$\checkmark$ 今

岳守密园

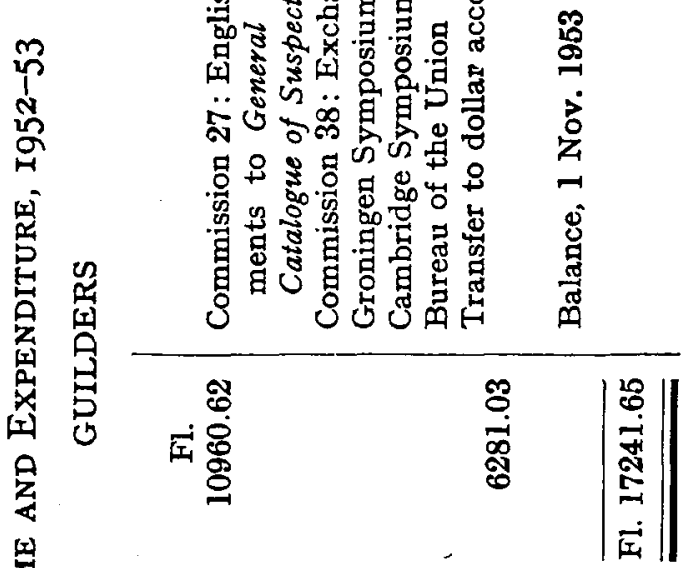

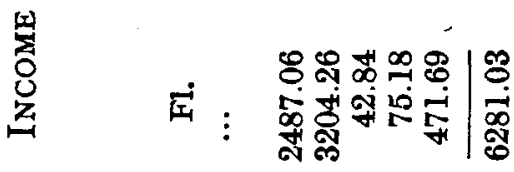

$\vdots \quad \vdots \vdots \vdots \vdots$

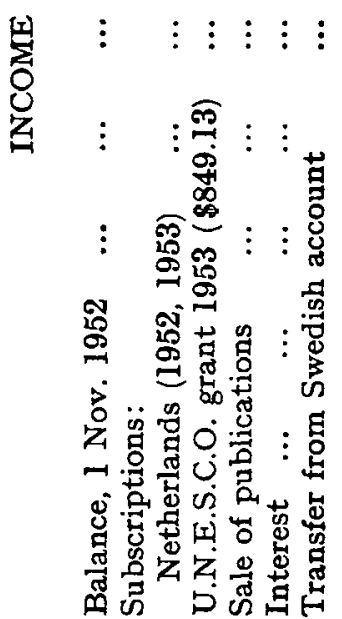




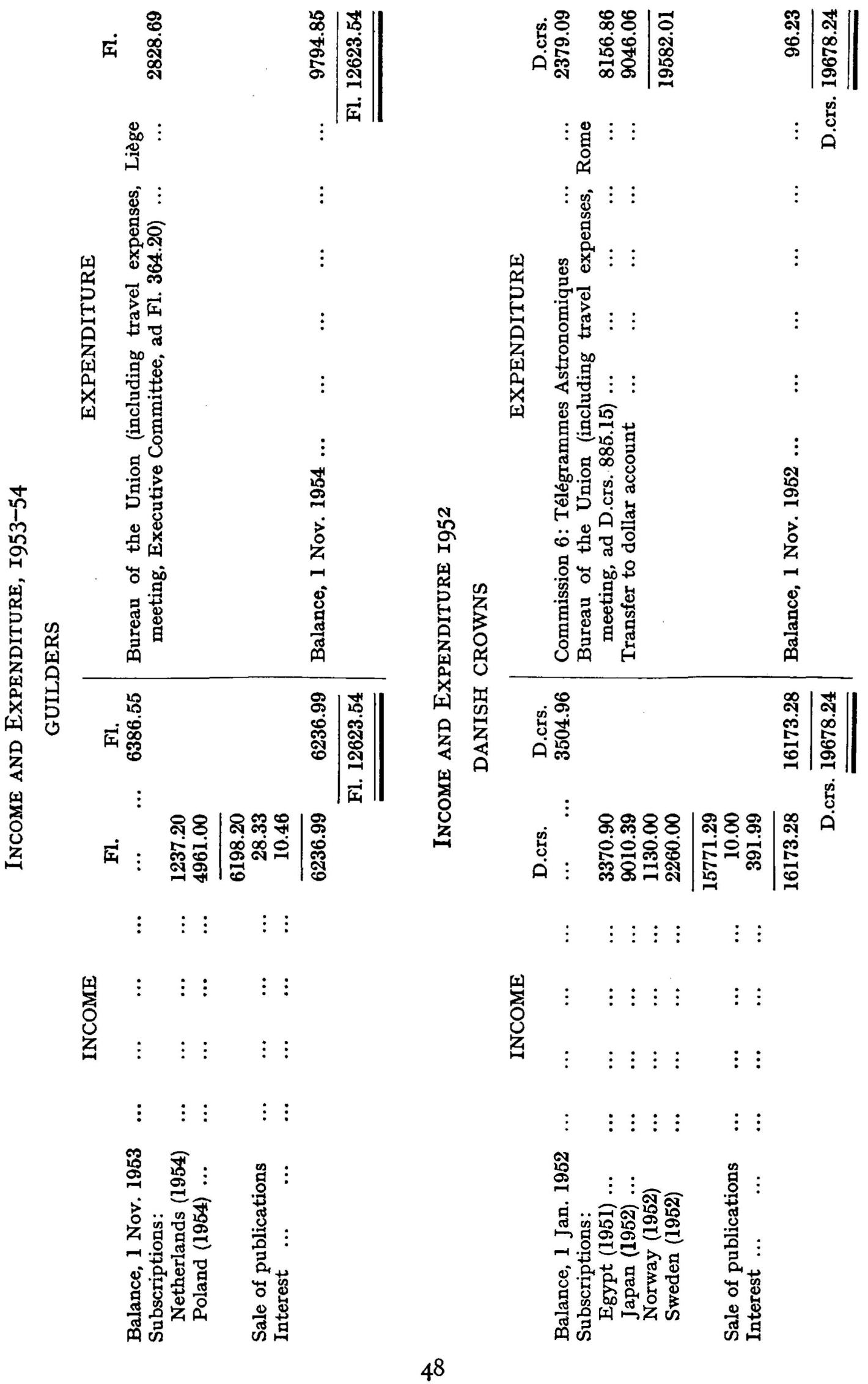




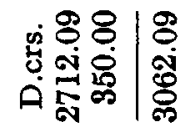

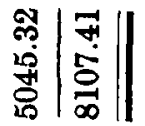

$\vdots \vdots$

: $\stackrel{0}{0}$

$\vdots \vdots$

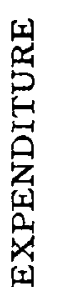

品

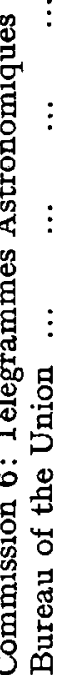

$\stackrel{3}{\mathfrak{1}}$

劉员

霅

究

望

它

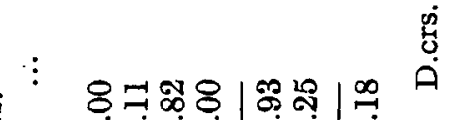

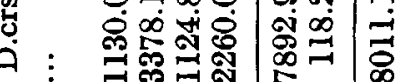

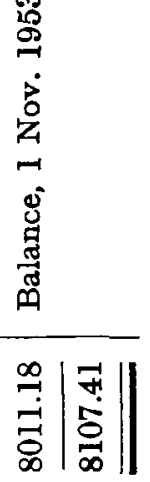

:

$\vdots \quad \vdots \vdots \vdots \quad \vdots$

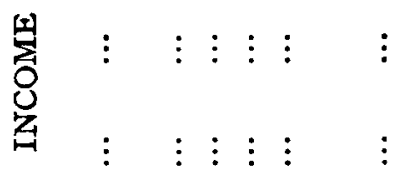

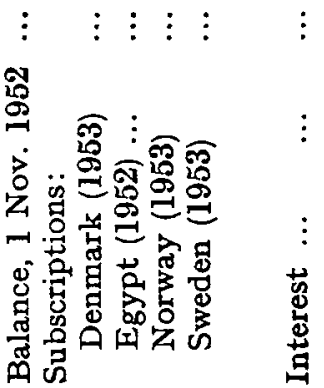

国 : :

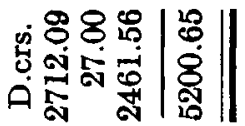

$\vdots \vdots \vdots \stackrel{\leftrightarrow}{\dot{0}}$

$\vdots \vdots \vdots$
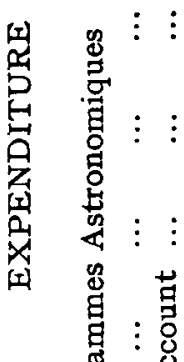

苾

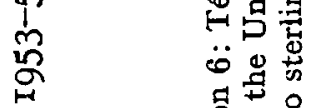

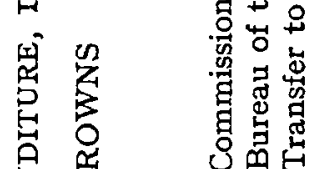

焉

果 $\quad \vdots \quad \stackrel{\dot{y}}{0}$

艺

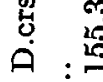

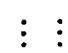

$\vdots:$

施: 


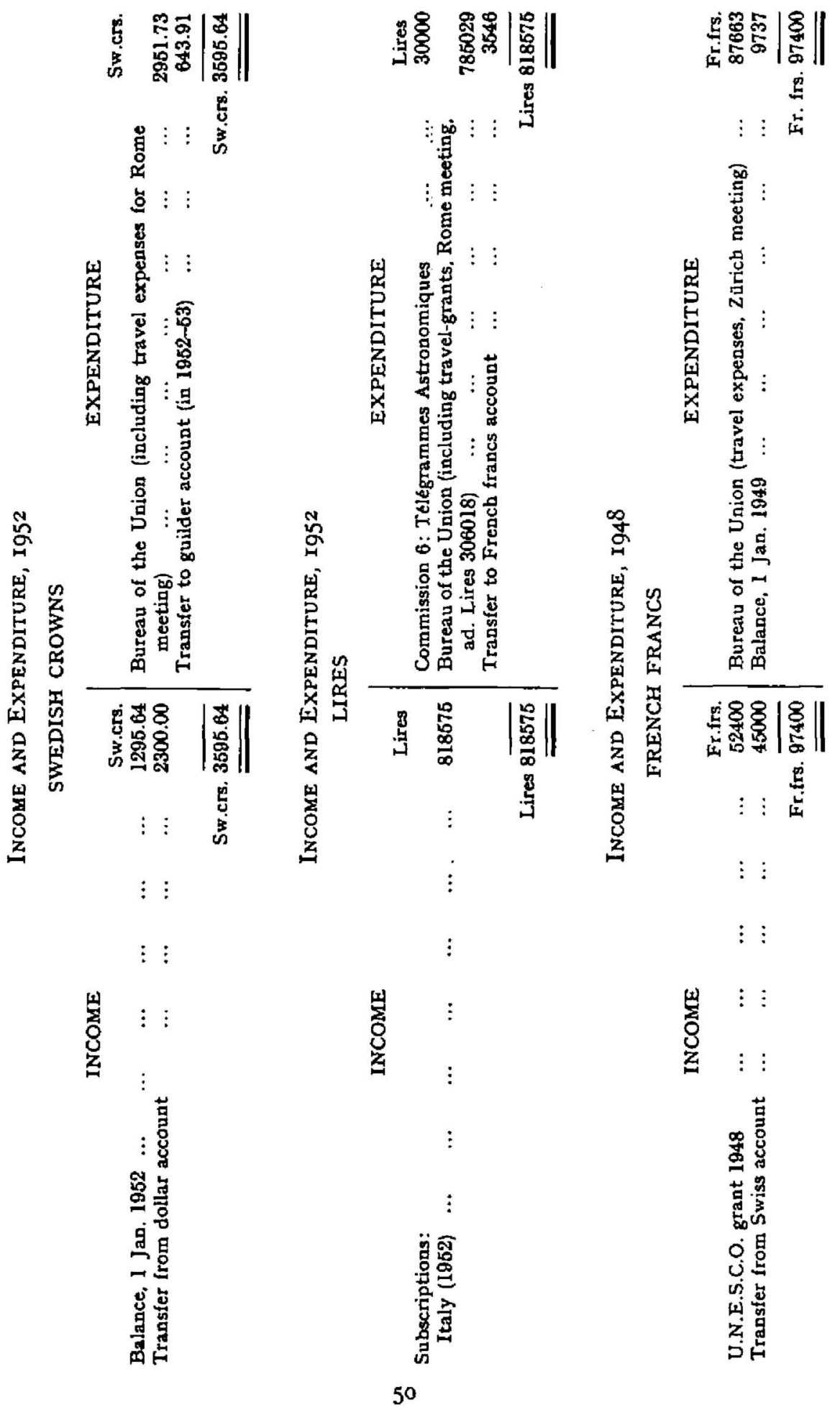




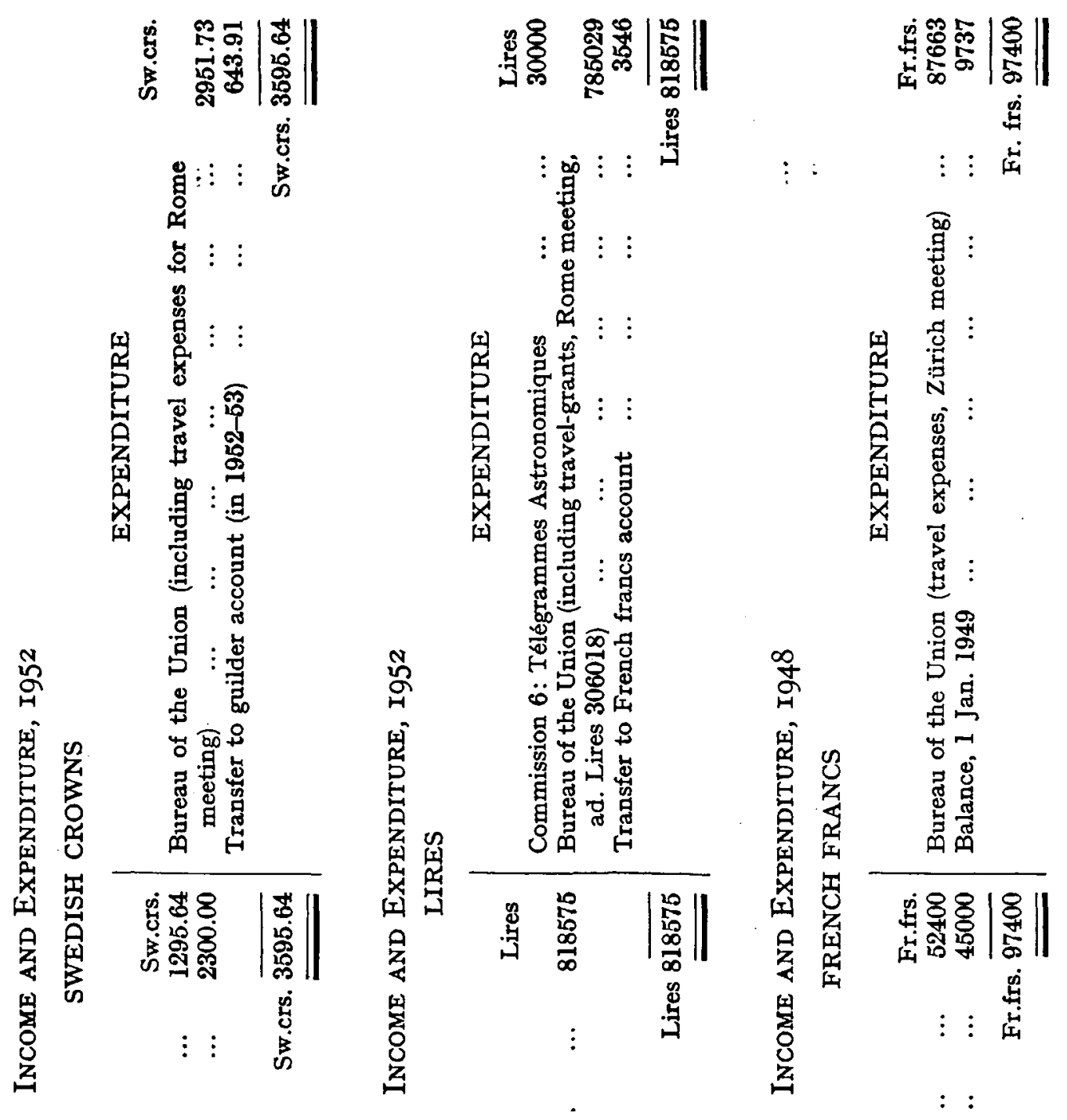



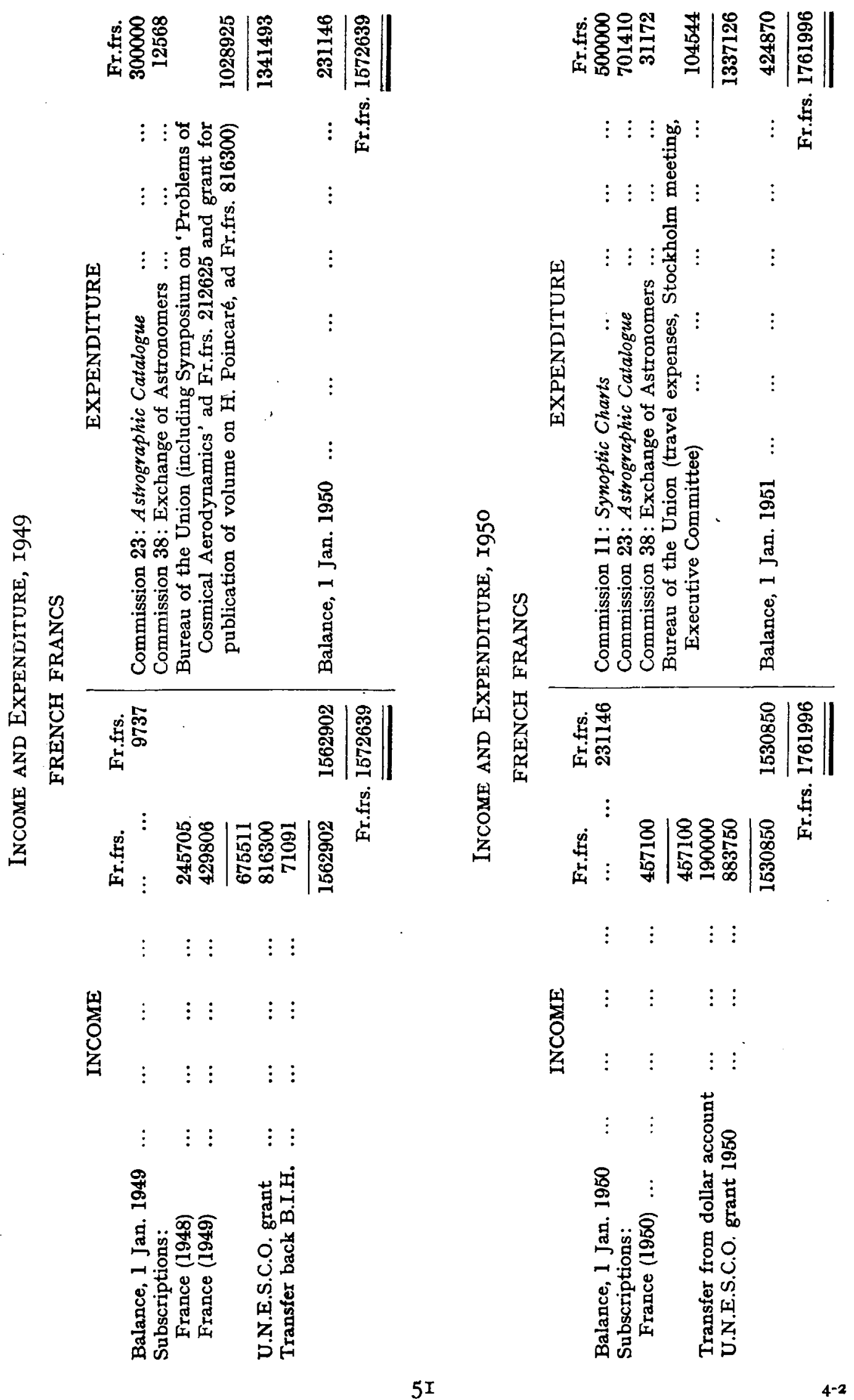

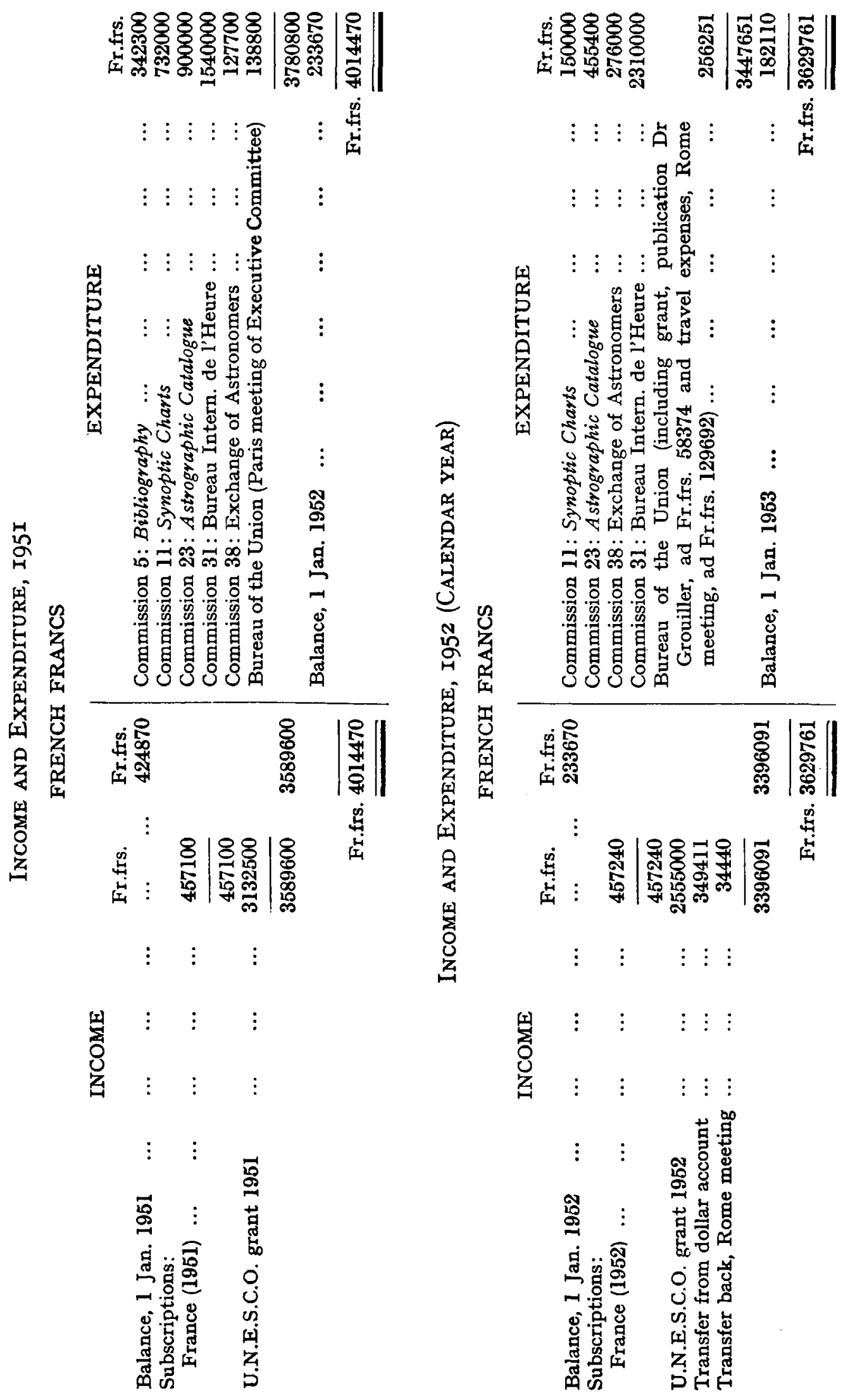


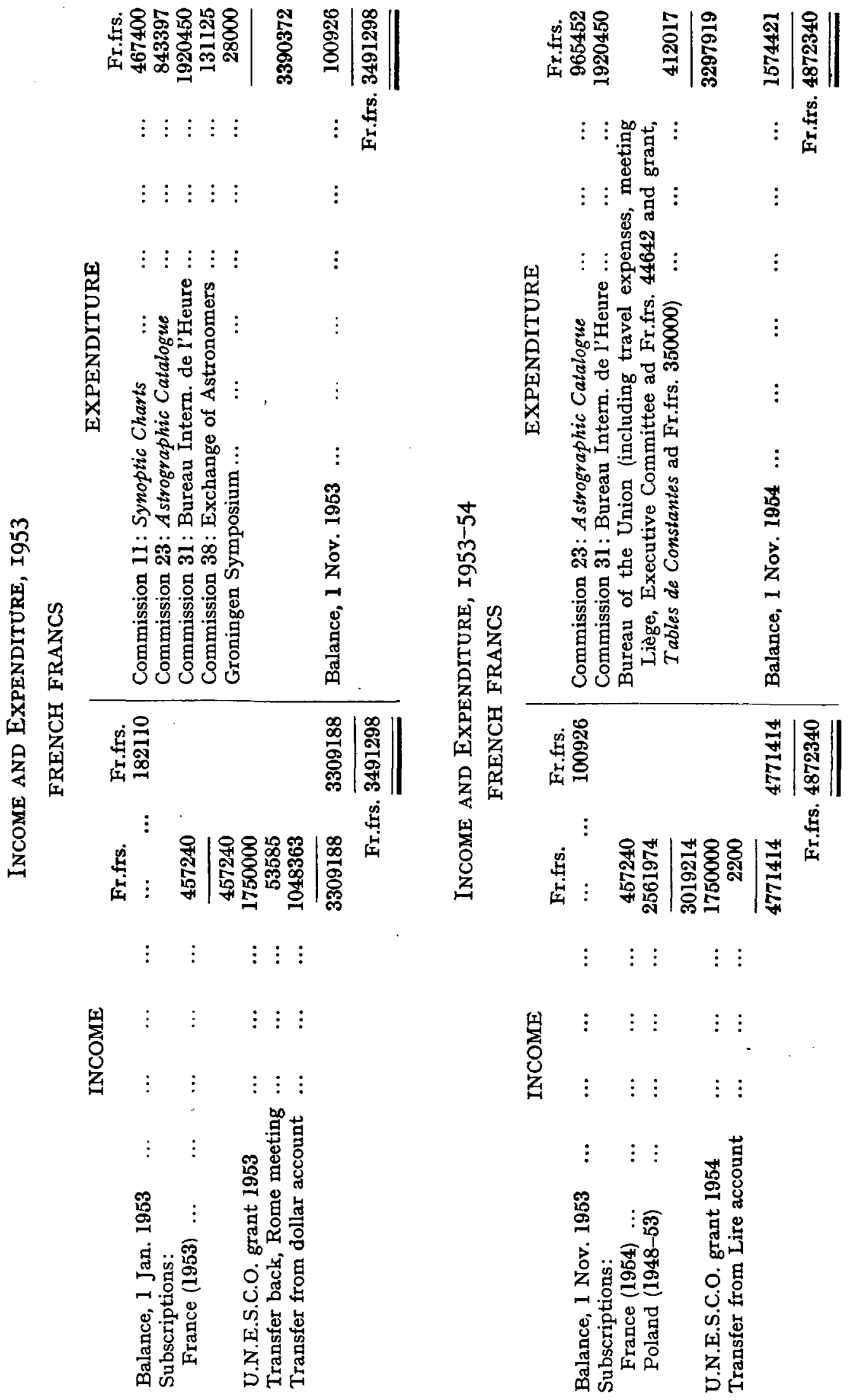

